\title{
Currency Policy in the Eurasian Economic Union: Prospects of Development
}

\author{
Maryna Markusenka \\ Belarusian State Economic University, Minsk, Republic of Belarus
}

\begin{abstract}
Countries of Eurasian Economic Union (EAEU) have a number of differences in currency policy now. Development of economic integration implies participating countries' (Russia, Belarus, Armenia, Kyrgyzstan, Kazakhstan) coherent currency policy. In the called paper: principles of a coherent currency policy in the Eurasian Economic Union are considered; differences in the currency exchange regulation and specific forms of common currency policy are defined; features of functioning banking systems of the countries of the EAEU are identified; the directions of currency policy coordination within the EAEU are developed; possible stages in the creation of a currency Union in the long term are dedicated.
\end{abstract}

Keywords: transitive economy, currency policy, economic integration, Eurasian Economic Union, exchange rate, restrictions, banks, common payment instrument

\section{Introduction}

The solution of the exchange rate problems is one of the main goals of the currency policy in the international integration conditions of the countries in transition. The changes of the real exchange rate influence the competitiveness of the country and its current account balance. The most difficult policy is that of the exchange rate in the countries of Common Economic Space (CES). CES was found on the basis of Customs union of Russia, Kazakhstan, and Belarus. This regional economic union started its activity from January 1, 2012.

The result of the further convergence of the economies of the countries of the post-Soviet space was the entry into force of the agreement on the Eurasian Economic Union (EAEU). A treaty aiming for the establishment of the EAEU was signed on May 29, 2014 by the leaders of Belarus, Kazakhstan, and Russia, and came into force on January 1, 2015. A new member of this Union became Armenia (02.01.2015) and Kirgizstan (12.08.2015).

The creation of such a Union is a new step in economic integration in the post-Soviet space. EAEU opens up broad prospects for economic development for its Member States. When developing integration of economy of Republic of Belarus into the Eurasian Economic Union (EAEU) reforming of the currency sphere becomes a necessary condition.

Maryna Markusenka, Ph.D. in Economics, associate professor, Department of Banking of the Belarusian State Economic University, Minsk, Republic of Belarus.

Correspondence concerning this article should be addressed to Maryna Markusenka, Belarusian State Economic University, Partizansky Ave. 26, Minsk 220070, Republic of Belarus. 


\section{Literature Review}

In economic literature, much attention is paid to international monetary and credit relations (Krasavina, 2005; Moiseev, 2004; 2007; Faminskii, 2004). Experts consider the problems of the functioning of the world monetary system (Sel \& Sauer, 2011; Tarachev \& Dedischev, 2011).

Various aspects of the integration between Russia, Belarus, and Kazakhstan with CIS-countries are discussed in the writings of scientists Shevchuk (2011), Sokolov (2011), Petrovich (2004), Petrov and Plisetsky (2011), and others.

Currency regulation measures remain an important part of government economic policy for countries with economies in transition. Some aspects of currency regulation are examined in the works of such Belarusian authors as Nikitenko (2009), Bainev and Saevich (2007), Luchenok (2017), Tarasov (2002), Tikhonov (2011), Kallaur (2010), Rudy (2008), and others. Special attention to the work of Belarusian researchers was focused on practical aspects of currency regulation and the functioning of the currency market. But a number of problems of foreign exchange policies and regulations are still unresolved.

Currency policy issues are discussed by scholars in the post-Soviet space (Nagovitsyn, 2001; others). It should be noted the approach according to which monetary policy is defined as an integral part of the national strategy for economic and social development of the country. It is aimed at realizing the objectives regarding the areas and mechanisms of integration into the world economic system (Scherbakov, 2000). When the notion of entity objectives of currency policy can be quite a wide range of economic problems, such an approach could be taken as a basis for the formation of the National currency strategy in the Republic of Belarus. In terms of development of economic integration, currency policy must take into account these processes.

The currency policy usually is understood as set of measures of state regulation in the field of currency-financial and credit attitudes. Objective of currency policy is regulation of the balance of payments, a rate of exchange, maintenance of stable functioning of national currency system.

In many developed states which completely have cancelled currency restrictions, distinctions between currency and a monetary policy at all are not done. Measures of currency policy are used in structure of a monetary policy in these countries. In conditions of transitive economy there are problems of regulation of the balance of payments, a choice of a mode of the exchange rate, as well as measures of regulation of the exchange rate. In this case allocation of currency policy from a monetary policy is appropriate.

The EAEU countries have a number of problems related to insufficient stability of exchange rates, the balance of payments and inflation.

\section{Principles of a Coherent Currency Policy in the Eurasian Economic Union}

EAEU provides a coordinated currency policy for its member countries. Such a policy is carried out in order to create the conditions to ensure the unhindered movement of capital between Member States in the Union.

Treaty includes the creation of harmonized approaches of Member States to regulate currency relations and their liberalization. It is provided in the contract that:

- currency transactions between residents of the states of EAEU will be carried out without obtaining permissions;

- it will not be required to receive them for opening and maintaining bank accounts of residents of one state member in authorized organizations of other state member; 
- currency limits for the calculations between residents of member countries connected with transfer of goods, with stock acquisition, a share, with introduction of deposits, with acquisition through the organized markets of member countries of the state securities and other securities with the translations of natural persons within EAEU and other currency transactions will be lifted.

The agreement also provides cancellation by state members of the requirement about obligatory sale of foreign currency for residents of the state. Listed above means need of liberalization of capital streams and the operating currency mode for the relations with other countries of EAEU for Belarus.

\section{Differences in the Currency Exchange Regulation and Specific Forms of Common Currency Policy}

The implementation of currency policy is carried out by means of currency regulation - regulation of State international settlements and of arrangements for currency operations at the national, intergovernmental, and regional levels. The main differences in measures of currency regulation used by EAEU-countries can be seen in Table 1.

Table 1

Comparative Analysis of Currency Exchange Regulation Areas in the EAEU

\begin{tabular}{|c|c|c|c|c|c|}
\hline $\begin{array}{l}\text { Currency exchange } \\
\text { regulations }\end{array}$ & $\begin{array}{l}\text { The Republic of } \\
\text { Belarus }\end{array}$ & $\begin{array}{l}\text { The Republic of } \\
\text { Kazakhstan }\end{array}$ & Russian Federation & $\begin{array}{l}\text { The Republic of } \\
\text { Armenia }\end{array}$ & $\begin{array}{l}\text { The Republic of } \\
\text { Kirgizstan }\end{array}$ \\
\hline Exchange rate regime & $\begin{array}{l}\text { Managed float of } \\
\text { the exchange rate }\end{array}$ & $\begin{array}{l}\text { Managed float of } \\
\text { the exchange rate }\end{array}$ & $\begin{array}{l}\text { Float of the } \\
\text { exchange rate } \\
\text { (from November } \\
2014 \text { ) }\end{array}$ & $\begin{array}{l}\text { Float of the } \\
\text { exchange rate }\end{array}$ & $\begin{array}{l}\text { Float of the } \\
\text { exchange rate }\end{array}$ \\
\hline $\begin{array}{l}\text { Limitations on the current } \\
\text { foreign exchange } \\
\text { transactions, including: }\end{array}$ & Applied & None & None & None & None \\
\hline $\begin{array}{l}\text { 1. Limitations on the } \\
\text { amounts of advance } \\
\text { payments related to imports } \\
\text { of goods and services }\end{array}$ & Applied & Does not apply & Does not apply & Does not apply & Does not apply \\
\hline $\begin{array}{l}\text { 2. Limitations on opening } \\
\text { accounts by nationals in } \\
\text { foreign banks }\end{array}$ & $\begin{array}{l}\text { Only with } \\
\text { permission of the } \\
\text { National bank }\end{array}$ & None & None & None & None \\
\hline $\begin{array}{l}\text { 3. Buying and selling by } \\
\text { individuals (nationals and } \\
\text { non-nationals) the foreign } \\
\text { currency through banks }\end{array}$ & $\begin{array}{l}\text { Without limitations } \\
\text { on the amounts }\end{array}$ & Without limitations & Without limitations & Without limitations & Without limitations \\
\hline $\begin{array}{l}\text { 4. Buying and selling by } \\
\text { business entities (nationals) } \\
\text { the foreign currency } \\
\text { through banks }\end{array}$ & $\begin{array}{l}\text { The purpose of the } \\
\text { purchase; use } \\
\text { within } 7 \text { days }\end{array}$ & Free & Free & Free & Free \\
\hline $\begin{array}{l}\text { 5. Limitations on opening } \\
\text { accounts by non-nationals } \\
\text { in domestic banks }\end{array}$ & None & None & None & None & None \\
\hline $\begin{array}{l}\text { 6. Operations concerning } \\
\text { with capital movements }\end{array}$ & $\begin{array}{l}\text { Only with } \\
\text { permission of the } \\
\text { National Bank }\end{array}$ & $\begin{array}{l}\text { The National Bank } \\
\text { needs to check the } \\
\text { validity of } \\
\text { transaction } \\
\text { (exchange } \\
\text { agreement) }\end{array}$ & $\begin{array}{l}\text { Without } \\
\text { permission of the } \\
\text { central bank }\end{array}$ & $\begin{array}{l}\text { Without } \\
\text { permission of the } \\
\text { central bank }\end{array}$ & $\begin{array}{l}\text { Residents are } \\
\text { required to register } \\
\text { in the Bank of } \\
\text { Kyrgyzstan } \\
\text { accounts and } \\
\text { deposits opened } \\
\text { outside the Kyrgyz } \\
\text { Republic }\end{array}$ \\
\hline
\end{tabular}

Source: Official website's information of EAEU-country's central banks. 
Currency restrictions are widely used in Belarus unlike Russia, Kazakhstan, Armenia, and Kirgizstan. Thus, only in the Republic of Belarus is there mandatory sale of hard currency proceeds by business entities (cancelled in Kazakhstan in 1999, in Russia in 2006), limitations on opening accounts by nationals in foreign banks.

The foreign exchange regime involves a number of significant restrictions in the current account of balance of payments (the terms for termination of foreign trade operations are limited; there are mechanisms for special-purpose buying of foreign currency at the domestic foreign exchange market) in the Republic of Belarus.

The central banks of EAEU countries and especially the National Bank of the Republic of Belarus must coordinate the use of currency restrictions. Pursuant to the established rules, the implementation of currency restrictions is possible in exceptional cases (negative dynamics of balance of payments, size reduction of gold and foreign currency reserves lower then the acceptable level, sharp fluctuations of exchange rates) for a period not exceeding one year. That is, currency restrictions are permitted in cases where a negative situation can not be changed by other economic measures.

The currency restrictions on capital movement implemented in Belarus helped minimize the risks while allowing foreign economic operations by Belarusian nationals. Nevertheless, the restrictions need to be phased out gradually within the agreements of EAEU-countries.

Any steps taken to abolish the currency restrictions will bring the expected benefits only if the state carries out the complex measures for improving the state of its economy as a whole, including the fight against inflation and the improvement of foreign exchange, tax, and customs regimes.

Currency policy is being developed by the central banks of countries of EAEU, and implements systems of commercial banks in those countries. Therefore, there is in the face of the need to establish a coherent monetary policy for the countries of EAEU to reach a comparable level of development of their banking systems.

\section{Features of Functioning Banking Systems of the Countries of EAEU}

Both common features and distinctions are characteristic of banking systems of state members of EAEU. All considered banking systems are two-level.

Investigating features of functioning of commercial banks of the countries of EAEU, it is necessary to pay attention to admissible legal forms of the organization of bank activity which is the closed joint stock company (CJSC), the open joint stock company (OJSC), a restricted liability society (Ltd company), cooperative bank.

The general for all banking systems of the Eurasian integration is the high level of concentration of bank assets which is that in all countries, except Kazakhstan, more than $50 \%$ of all assets of the banking sector are the share of five largest banks.

Set of commercial banks of the countries of EAEU in a general view can be characterized by data of Table 2.

As can be seen from the table, the number of commercial banks in all countries with the exception of the Russian Federation varies approximately in the same range.

In Republic of Belarus the banking system includes 24 banks. Treat the largest banks as JSC ASB Belarusbank, JSC Belagroprombank, JSC Priorbank, JSC BPS-Sberbank, JSC Belinvestbank. 
Table 2

General Characteristics of the Commercial Banks of the EAEU

\begin{tabular}{lll}
\hline EAEU member country & $\begin{array}{l}\text { The number of commercial banks } \\
\text { (on 01.01.2017) }\end{array}$ & $\begin{array}{l}\text { Total capital of commercial banks, millions } \\
\text { USD (01.01.2017) }\end{array}$ \\
\hline The Republic of Armenia & 20 & 340.2 \\
The Republic of Belarus & 24 & 319.4 \\
The Republic of Kazakhstan & 34 & 981.2 \\
The Kyrgyz Republic & 25 & 278.2 \\
Russian Federation & 575 & $1,300.0$ \\
\hline
\end{tabular}

Source: Official website's information of EAEU-country's central banks.

Except large banks, average and small banks work at the market. So, it is possible to carry CJSC MTbank to dynamically developing banks. CJSC MTbank was created in 1994 and became the Republic of Belarus' first bank with participation of the foreign capital. Now customer service is conducted in 127 branches of the bank located across all Republic of Belarus.

CJSC MTbank is the member of Association of the Belarusian banks, Communities of the World Interbank Financial Communications (S.W.I.F.T.), international payment service providers VISA International and MasterCard. Since the beginning of the activity the Bank is universal and has reputation of reliable bank in the Belarusian market. MTbank actively cooperates with JSC Development Bank of Republic of Belarus and the international financial institutions as the European Bank for Reconstruction and Development (EBRD), the International Finance Corporation (IFC). In 2016 MTbank was entitled the best Belarusian bank, having become the owner of the Grand Prix of the award "Bank of Year-2015".

The common features also include: the limited role of banks in financing growth and modernization of the economy; comparable for all Member States at the level of capitalization of banks EAEU in relation to assets; level of arrears on loans (except Armenia) (Table 3).

Table 3

Assessment of the Condition of the Banking Sector According to the Results of the EAEU, 2016

\begin{tabular}{|c|c|c|c|c|c|}
\hline Indicators & $\begin{array}{l}\text { The Republic of } \\
\text { Armenia }\end{array}$ & $\begin{array}{l}\text { The Republic of } \\
\text { Belarus }\end{array}$ & $\begin{array}{l}\text { The Republic of } \\
\text { Kazakhstan }\end{array}$ & $\begin{array}{l}\text { The Kyrgyz } \\
\text { Republic }\end{array}$ & $\begin{array}{l}\text { Russian } \\
\text { Federation }\end{array}$ \\
\hline Assets of the banking sector to GDP, \% & 76.9 & 67.22 & 63.1 & 38.9 & 93.1 \\
\hline $\begin{array}{l}\text { Five largest banks assets to total banking } \\
\text { assets, \% }\end{array}$ & 47.0 & 78.0 & 66.0 & 53.0 & 55.0 \\
\hline Capital to banking assets, $\%$ & 16.2 & 13.46 & 37.4 & 16.6 & 12.5 \\
\hline $\begin{array}{l}\text { Overdue on loans to total loans of } \\
\text { banks, } \%\end{array}$ & 9.5 & 4.9 & 6.7 & - & 6.8 \\
\hline Liabilities to GDP, \% & 66.7 & 58.5 & 69.8 & 32.7 & 37.3 \\
\hline
\end{tabular}

Source: Official website's information of EAEU-country's central banks.

In principle the difference between banking systems includes the implementation of payments in the territory of each State in their national currency vis-à-vis the United States dollar which varies considerably (Table 4).

Despite the differences, development of banking systems of member countries in recent years, EAEU goes towards improving the financial stability and openness. This creates the conditions for the formation and implementation of a coherent currency policy. 
Table 4

The National Currencies of the Member Countries of Eurasian Economic Integration

\begin{tabular}{llllll}
\hline & $\begin{array}{l}\text { The Republic of } \\
\text { Armenia }\end{array}$ & $\begin{array}{l}\text { The Republic of } \\
\text { Belarus }\end{array}$ & $\begin{array}{l}\text { The Republic of } \\
\text { Kazakhstan }\end{array}$ & $\begin{array}{l}\text { The Kyrgyz } \\
\text { Republic }\end{array}$ & Russian Federation \\
\hline $\begin{array}{l}\text { The name of the national } \\
\text { currency }\end{array}$ & Armenian dram & Belarussian ruble & Kazakhstani tenge & Kyrgyz som & Russian ruble \\
$\begin{array}{l}\text { Designation of national } \\
\text { currenc }\end{array}$ & AMD & BYN & KZT & KGS & RUB \\
$\begin{array}{l}\text { The exchange rate to } \$ 1 \\
(01.01 .2017)\end{array}$ & 483.94 & 1.9585 & 311.76 & 69.2301 & 60.6569 \\
\hline
\end{tabular}

Source: Official website's information of EAEU-country's central banks.

\section{The Directions of Currency Policy Coordination Within the EAEU}

The global economy, as the country's national economy, on the one hand, is the system capable to regulate itself, and on the other hand, is an active state regulation (with priority to economic, not administrative methods).

The Coordinated Principles of Currency Policy of EAEU countries are included in the Agreement on the Eurasian Economic Union of 29.05.2014. The given agreement provides for the adoption of currency policy by the parties based on the principle of gradual harmonization. The currency policy of countries should be aimed at building confidence in local currencies both in every state-participant and at the international currency markets. The major aims of the agreement are that the EAEU countries should:

- coordinate the exchange rate policy to expand the use of local currencies in mutual payments;

- ensure the convertibility of local currencies in the current and capital transactions of balance of payments. This suggests that there are no restrictions on exchange transactions for nationals;

- create the conditions for mutual direct quotations of local currencies;

- avoid a multiplicity of exchange rates;

- set the official exchange rate on the basis of rates formed in the exchange market (or on the basis of rates against the U.S. dollar);

- form an integrated currency market;

- arrange the access for banks of EAEU countries at the national foreign exchange market for interbank FX transactions on terms no less favorable than for native banks;

- create conditions for the allocation of foreign-exchange holdings of EAEU countries' central banks in the local currencies of participating countries, including also public securities.

Thus, the necessity of keeping the exchange fluctuations of the currencies relative to each other within a limited range is the primary obligation of EAEU countries under the Agreement.

Developed principles and criteria are the basis for monetary integration in the Eurasian Economic Union. Currency policy in Eurasian Economic Union will be based on the agreements of member-countries signed within the framework of the Common Economic Space.

The high dollarization of mutual payments and the low proportion of local currencies in the mutual payments are the main problem in the currency payment relations of the EAEU countries today. At the same time, the share of Russian rubles in trade among EAEU countries is big enough. It is essential to increase the share of payments in local currencies in terms of the foreign economic turnover of countries. This will help increase their foreign trade turnover, the economic growth, and the utilization of integration benefits. 
Today the currencies of the EAEU countries are exchanged with each other primarily through the U.S. dollar. This situation leads not only to excessive growth of transaction costs, but also to foreign currency risks, as partners of the two countries become dependent on the U.S. dollar dynamics in the international monetary markets. The EAEU countries should ensure the mutual convertibility of the currencies. As a result, the participants of foreign economic relations could use the local currencies in mutual payments. They could reduce the cost of bank charges and significantly minimize the necessity for hard currency (Petrov \& Plisetskiy, 2011; Raskov, 2011).

Therefore, in the short term, the most important measures in the sphere of currency and financial cooperation of the EAEU countries should be as follows:

1. The expansion of the use of local currencies is used in mutual trade. It is necessary to create conditions conducive to conclusion of contracts in local currencies. The system of current exchange rate quotations of local currencies of Belarus, Russia, Armenia, Kyrgyz Republic, and Kazakhstan is not suitable.

2. The establishment of a consolidated monetary and financial market and information market of three countries will strengthen the competitive positions of national enterprises.

3. Realizing unification of rules of the exchange transactions both for nationals and for non-nationals in three counties is required.

The next step after the abolition of currency restrictions should be the development of a common payment instrument.

It is possible:

- to use the monetary unit of one of the EAEU countries as a common payment instrument;

- to use a new currency as a common payment instrument.

The practice of the International Monetary Fund as per SDR (special drawing rights) confirms that some countries will be able to accumulate a currency surplus at their current accounts as a result of a surplus of foreign trade turnover. Common payment instrument will primarily be used in the official disposal between the central banks of countries and a common issuing center of EAEU.

The Central Bank of EAEU will determine the general mechanism of common payment instrument development.

The central banks of EAEU countries will be able to store the reserves in the Central Bank of the EAEU. These reserves will be set in the common payment instrument. The further issue of common payment instrument will use it as a reserve currency for central banks of EAEU countries.

There is a problem in the official disposal of common payment instrument (CPI) implementation in private disposal for all economic entities of member countries involved in foreign trade relations. In this case, the commercial banks of three states will have to be the providers of common payment instrument to the real economy.

The use of common payment instrument will create the opportunities for settlement system working on export-import transactions among the EAEU countries.

There is the possibility of using the Russian ruble as a common payment instrument.

In the case that the Russian ruble is used as a common payment instrument, the following positive and negative consequences for the Republic of Belarus can be highlighted. These consequences will be approximately the same as expected to be for the adoption of Russian ruble as the common EAEU currency within the Union State of Belarus and Russia in 2004 (Table 5) (Petrovich, 2004). 
The positive effects of Russian ruble implementation as a common payment instrument for the economy of the Republic of Belarus may show up for the short term. At the same time, in case of negative effects, they will lead to negative impact in the long-run. With respect to this case, the situation is similar in Kazakhstan, etc. Therefore, the use of the Russian ruble as a common payment instrument for the Republic of Belarus would be undesirable.

The development of the EAEU will be made most effective by using a new supranational currency as a common payment instrument.

Table 5

Positive and Negative Consequences of Implementation of the Russian Ruble as the CPI for the Republic of Belarus

\begin{tabular}{|c|c|}
\hline Negative consequences & Positive consequences \\
\hline $\begin{array}{l}\text { 1. Long-term decreases in price competitiveness of } \\
\text { Belarusian exports }\end{array}$ & $\begin{array}{l}\text { 1. Minimal organizational, legal and time expenditures for } \\
\text { establishment of a currency union }\end{array}$ \\
\hline $\begin{array}{l}\text { 2. The displacement of the western imports by Russian } \\
\text { imports }\end{array}$ & $\begin{array}{l}\text { 2. The structural simplicity of the construction of a currency union } \\
\text { infrastructure }\end{array}$ \\
\hline 3. Loss of ability to control the basic monetary indicators & $\begin{array}{l}\text { 3. Immediate removal of external barriers in mutual settlements of } \\
\text { economic entities }\end{array}$ \\
\hline 4. Limitations imposed on government expenditure policy & 4. Price reduction for imported consumer goods from Russia \\
\hline 5. Loss of seigniorage & 5. Production cost reduction for Belarusian products \\
\hline 6. Disabled monetary financing of government programs & 6. Increase of foreign trade turnover with Russia \\
\hline \multirow[t]{2}{*}{ 7. Giving a subordinate character to the Belarusian economy } & 7. Wage growth \\
\hline & 8. High stability of exchange rate formation \\
\hline
\end{tabular}

It is possible to establish something akin to the European Central Bank, in the form of the so-called Central Bank of EAEU, which would act as the emission center.

The membership should consist of representatives of the three countries. The coordination of legislation related to the banking sector, as well as the securities markets in Belarus, Kazakhstan, Russia, Armenia, and Kirgistan is required.

Thus, the process of currency integration in the EAEU may be conducted in three phases:

(1) realization of cooperation during the arrangement of payments between the three countries, the coordination of currency and monetary policies. Russian banks have already entered the markets of the EAEU partners, looking to buy shares in their credit institutions;

(2) coordination of exchange rate policies, development of a common payment instrument, and creation of the Central Bank;

(3) adoption of a common currency and establishment of the monetary union.

The establishment of a common monetary area (Stage 3) is possible only in the long-term perspective. The problems appear that EU should serve as benchmarks to consider while developing the common monetary area. The crisis has shown, it is useful for countries to handle the emission on their own so that in case of crisis there is an opportunity to devalue the local currency and minimize the problems with the budget deficit and public debt.

A complex of measures to regulate the EAEU exchange market on the basis of new criteria is need. It includes:

- measures to increase liquidity of the currency market, which means that the construction process of buying and selling currencies is easy and affordable for each participant; 
- measures to increase the transparency of the currency market, which is possible due to the publication of information by banks about volume of currency trading; and reference module open currency positions - summary information for aggregate open currency positions clients;

- measures to control and reduce the level of risk in the foreign exchange market, which provides for the regulation of the currency market in order to increase its effectiveness.

As a result of changes in the organization of elements in the currency system, they will contribute the transition to a new system of relations, a new structure of the foreign exchange market.

\section{Conclusions}

(1) In conditions of transitive economy there are problems of regulation of the balance of payments, a choice of a mode of the exchange rate, as well as measures of regulation of the exchange rate. This calls for the allocation of currency policy as part of monetary policy.

(2) In terms of development of economic integration among countries of EAEU there is a need to implement a coherent currency policy which should be based on agreed principles.

(3) It is essential to increase the share of payments in local currencies in the foreign economic turnover of countries. The EAEU countries should ensure the mutual convertibility of their respective currencies. The banking systems of the participating countries must have a comparable level of development.

(4) Along with the establishment of the EAEU central bank the methodology of local currency exchange rate determination should be defined. The development of mechanism for determination of the exchange rate of local national currencies against the common payment instrument is necessary.

Then the participating countries of EAEU can set the exchange rates of the local currencies against other currencies, and against unified common payment instrument on the basis of a common approach.

(5) The process of currency integration and the establishment of common currency area within EAEU can be realized in three stages: a) cooperation in the field of payments between the countries, coordination of monetary and currency policy; b) coordination of exchange rates policy, development of a unified payment instrument, and creation of an EAEU central bank; c) implementation of a common currency and establishment of a currency union. The establishment of a common monetary area is possible only in the long-term perspective.

\section{References}

Bainev, V. F., \& Saevich, V. V. (2007). Transition to innovative economy in the context of inter-state integration: Trends, challenges, the Belarusian experience (p. 178). Minsk: Law and Economics.

Faminskiy, I. (2004). International economic relations: Teaching aid (p. 645). M.: The Economist.

Kallaur, P. (2010). Financial stability as a goal of Central Bank. Bank Messenger, 2, 5-10.

Krasavina, L. (2005). International currency and credit and financial relations: Teaching aid (p. 576). M: Finance and Statistics. Luchenok, A. I. (2017). Institutional instruments of economic reform. Development of economy, politics, society: State, problems and prospects, Spb, Spb. Econ. University, 6, 10-16.

Moiseev, S. (2004). Macroanalysis of exchange rate: From Cassel to Obstfield and Rogoff. Economic Issues, 1, 12-19.

Moiseev, S. (2007). International currency and credit relations: Teaching aid (2nd ed., revised and updated). M: DiS, 816.

Nagovitsyn, A. G. (2001). Currency policy (p. 512). M.: Examination.

Nikitenko, P. G. (2009). Anti-crisis model of life of Belarus (p. 379). Institute of Economics of NAS of Belarus. Minsk: Law and Economics.

Petrov, M., \& Plisetskiy, D. (2011). The opportunities and prospects of CIS countries integration in the financial sector. Finance and Credit, 8, 38-48. 
Petrovich, A. (2004). Monetary integration of the European Union: Experiences for the CIS countries (p. 160). Minsk: Foreign Ltd "Law and Economy".

Raskov, N. (2011). Foreign trade imbalances and monetary policy. The Economist, 1, 33-41.

Rudy, K. (2008). Optimal exchange rate policy in the Republic of Belarus. Bank Messenger, 2, 34-41.

Sel, F., \& Sauer, B. (2011). Is it possible a new world monetary system? Journal of the Association of Belarusian Banks, $10,19-21$. Scherbakov, S. G. (2000). To the issue of and exchange rate policy. Money and Credit, 11, 43-48.

Shevchuk, I. V. (2011). About theoretical approaches to the modification of exchange rate policy. Money and Credit, 4, 50-55.

Sokolov, V. (2011). Euro-zone: The current stage. Money and Credit, 8, 46-52.

Tarachev, V., \& Dedischev, A. (2011). Will the currency wars bring to a new monetary structure? Banking, 4, 17-22.

Tarasov, V. I. (2002). The regulation of foreign exchange and its instruments. Journal of the Association of Belarusian Banks, 32, $23-25$.

Tikhonov, A. O. (2011). The modern version of the Triffin dilemma: We need a new international currency. Bank Messenger, 16, $11-13$. 